\title{
RECENT GLACIER CHANGES IN SOUTHERN CHILE AND IN THE ANTARCTIC PENINSULA
}

\author{
CAMBIOS RECIENTES EN LOS GLACIARES DEL SUR DE \\ CHILE Y EN LA PENÍNSULA ANTÁRTICA
}

Andrés Rivera $^{1,2}$, Francisca Bown ${ }^{1}$, Anja Wendt ${ }^{1} \&$ Claudio Bravo ${ }^{1}$

\section{RESUMEN}

Se presenta una síntesis de la investigación glaciológica reciente realizada por el Centro de Estudios Científicos, CECS, en Chile y la Península Antártica mediante el uso de una variedad de metodologías modernas, con el fin de detectar las tendencias de cambio experimentadas por los glaciares en las últimas décadas.

Palabras clave: Actividad volcánica, cambios frontales, de velocidad y de espesor de glaciares, colapso de plataformas de hielo flotantes.

\section{ABSTRACT}

A synthesis is presented of the recent glaciological research done by Centro de Estudios Científicos, CECS, in Chile and the Antarctic Peninsula by using a variety of modern methodologies with the aim of detecting glacier change trends throughout recent decades.

Key words: Volcanic activity, glacier frontal, thickness and velocity changes, ice shelves collapse. 


\section{INTRODUCTION}

In historical times, glaciers in Southern Chile have experienced a significant area reduction mainly in response to ongoing atmospheric warming. Here we present some of the research that has been done by Centro de Estudios Científicos, CECS, Valdivia, during recent years. This research has been conducted by means of direct glacier measurements, airborne data collection and remotely sensed satellite imagery analysis. Visible to near infrared images were employed to study active ice-capped volcanoes with the aim of monitoring possible volcanic activity effects on recent glacier behaviors. Several field campaigns have been also conducted to the Northern and Southern Patagonian Icefields (NPI and SPI respectively), where automatic weather stations, continuous GPS stations and time-lapse cameras have been used to survey glaciers. In 2002 and 2008, these icefields were surveyed with a Chilean Navy P3 airplane equipped with a laser and radar from NASA, and other sensors from CECS. In the Antarctic Peninsula (AP), during recent decades several ice shelves have collapsed, affecting upstream glaciers. In order to study these changes, field campaigns have been conducted to Adelaide Island (2002) and Fleming glacier (2007, 2008 and 2009) where ice thicknesses, ice velocities and local meteorological conditions have been measured. Airborne surveys have been conducted to the whole Antarctica Peninsula onboard a Chilean Navy P3 airplane equipped with CECS and NASA instruments in 2002, 2004 and 2008. In addition, the CECS airborne mapping system (CAMS) mounted onboard a Chilean Air Force (FACH) Twin Otter, was used in 2008 to survey the surface topography of Fleming.

\section{MAIN RESULTS}

- Glaciers of Southern Chile have been shrinking in recent decades, however some glaciers have experienced "anomalous" behaviors, especially if they are calving into fjords or lakes, or if they are located on top of active volcanoes. In general, glaciers located on active volcanoes have shown negative changes, as a primary response to regional climate warming at multidecadal timescales, however superimposed on this trend, volcanic activity is thought to impact glaciers in different directions. One of the study sites is Volcán Villarrica (39²5'S, 7156'W; 2847 $\mathrm{m}$ a.s.l.), where the glacier areal and frontal changes are thought to be enhanced by very frequent volcanic events (four since 1977). Volcán Hudson (455'ㅇ, 72 $58^{\circ} \mathrm{W}$; $1905 \mathrm{~m}$ a.s.l.) experienced an explosive eruption in 1991 that destroyed most of the glacier infilling the caldera, provoking huge lahar flows descending through Glaciar Huemules and Río Ibáñez. Ice elevation changes of Glaciar Huemules yielded a mean thinning rate of $-2.4 \mathrm{~m}$ $\mathrm{a}^{-1}$ in the period 1974-2009 which is synchronous to its strong snout retreat (Fig. 1). Although it cannot be strictly associated to the eruption effect of 1991 , the enhanced ice thinning and frontal change seem possibly related to this eruptive cycle, which remains one of the largest in Chile during historical times. In contrast, the negative long-term (1961 to 2007) frontal glacier trend observed at Volcán Michinmahuida (42 50 'S, $72^{\circ} 27^{\prime} \mathrm{W}, 2450 \mathrm{~m}$ a.s.l.) was reverted between 2008 and 2009, most probably in response to the explosive eruption of nearby Volcán Chaitén which began in May 2008 (Rivera et al. 2012a).

- The majority of the main glaciers in western Patagonia and southern Chile are calving into fjords or lakes, surrounded by rough mountainous terrains receiving high annual precipitation, ranging from about 3,500 $\mathrm{mm}$ (Isla San Pedro, $47.72^{\circ} \mathrm{S}$ at sea level) to more than $10,000 \mathrm{~mm}$ at the upper plateau of the SPI. Precipitation series measured at low altitude stations of western Patagonia have shown a secular decreasing trend, however, since the 1980s at least one of the southernmost stations (Evangelistas, $52.4^{\circ} \mathrm{S}$, at sea level) has registered a sharp increase in precipitation (Aravena \& Luckman 2009). Using NCEP-NCAR 40 years reanalysis data obtained at grid points equally spaced between $42.5^{\circ} \mathrm{S}$ and $55^{\circ} \mathrm{S}$ and between $70^{\circ} \mathrm{W}$ and $77.5^{\circ} \mathrm{W}$, Rasmussen et al. (2007) detected a warming trend at $850 \mathrm{hPa}$ of $\sim 0.5^{\circ} \mathrm{C}$ over 40 years between 1960 and 1999 at both, winter and summer months. As a result to these climatic changes, glaciers have experienced a generalized retreat and thinning, especially in the Northern Patagonia Icefield (Rivera et al., 2007) and in the north-western side of the Southern Patagonia Icefield (Glaciares Jorge Montt, Bernardo and Témpanos) and in the South western side (Amalia). An updated inventory in the whole SPI has revealed significant area losses according to a general ice wasting trend reported earlier (Aniya et al. 1997; 


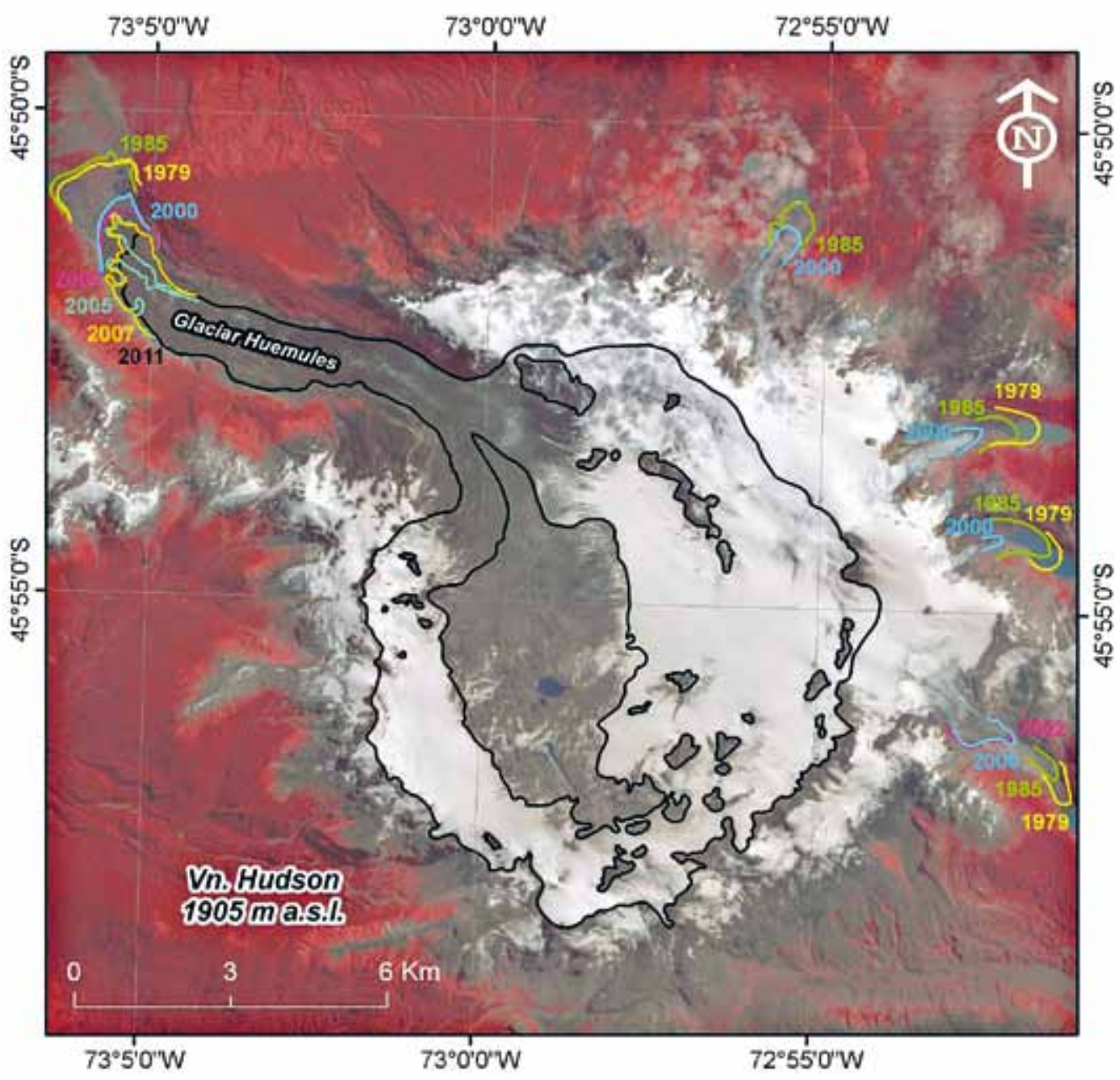

Fig. 1. Main glacier basin of Glaciar Huemules and frontal variations at Volcán Hudson between 1979 and 2011 . Background satellite image is a 3-2-1 composite ASTER scene collected in March 2, 2002.

Rignot et al. 2003), showing a total area reduction of $321.4 \mathrm{~km}^{2}$ in the period $1986-2000$. These retreats have triggered among other processes, ice-dammed lake outburst floods affecting downstream valleys and fjords. In spite of these retreats, the glacier with the longest historical record in Chile (Pío XI, $49^{\circ} \mathrm{S}$ ), is still at a maximum holocenic position, due to an advance detected until September of 2009. In the Torres del Paine National Park, all glaciers are experiencing significant retreats, with one of the biggest single calving events registered at Glaciar Grey $\left(51^{\circ} \mathrm{S}\right)$, and the opening of a new lake branch of Lago Dickson (5047'S), now an international lake, as a consequence of the retreat of the homonymous glacier (Rivera \& Casassa 2004). Glaciar Jorge Montt
(48 $20 ' S$ ), one of the largest tidewater glaciers of the SPI, experienced the greatest recorded retreat in South America, accounting for a frontal change of more than $19 \mathrm{~km}$ since 1898 in an apparently dynamic response to the near flotation conditions of the glacier tongue (Rivera et al. 2012b). Since 2000, the glacier has been retreating at rates between 100 and $400 \mathrm{~m} \mathrm{a}^{-1}$ (Rivera et al. 2012c).

- The first complete glacier inventory of the islands south of the Estrecho de Magallanes including Tierra del Fuego, Isla Santa Inés, Monte Sarmiento and Isla Hoste, was obtained by means of the analysis of several ASTER and Landsat ETM+ satellite images acquired between 1986 and 2006, yielding a total area of $3289 \mathrm{~km}^{2}$ of ice, distributed 


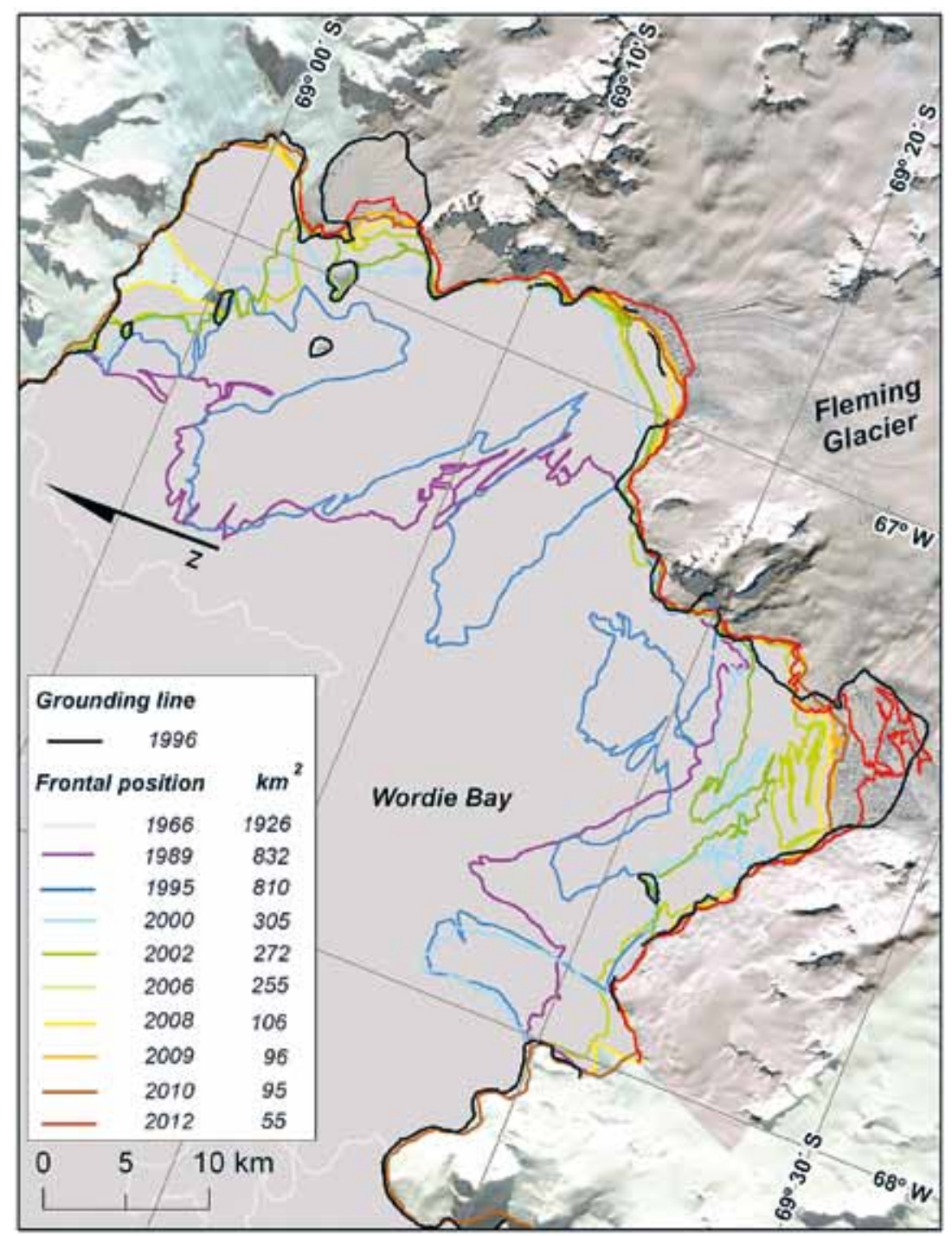

Fig. 2. Wordie Ice shelf between 1966 and 2012 (updated from Wendt et al., 2010), and total areas assuming no change of the grounding line dated in 1996 by Rignot et al. (2005).

among 1681 glaciers. Previous estimations of the total glaciated areas for these islands amounted to only $2500 \mathrm{~km}^{2}$, the difference being attributed to more precise glacier delimitation, and not to glacier advances (Bown et al. accepted). The southernmost glaciers in western Patagonia have also been retreating, being remarkable the glaciers at Monte Sarmiento (54 $27^{\prime}$ 'S) firstly described by Fitz Roy (1839), which compared to more recent satellite data is yielding an overall retreat of several $\mathrm{km}$. Many other glacier tongues analyzed from recent remotely sensed imagery have been compared to historical data, with a number of glaciers experiencing retreat in recent decades, especially on the northern side of Cordillera Darwin (54 $\left.35^{\circ} \mathrm{S}\right)$, located on Isla de Tierra del Fuego. Glaciar Marinelli showed the maximum amount of ice lost, with a frontal retreat of $13.6 \mathrm{~km}$ between 1913 and 2006 (Porter \& Santana 2003). However, Homlund \& Fuenzalida (1995) described the contrasting behavior between mainly retreating glaciers on the northern flanks and glaciers seen advancing in the south. In fact many 
glacier fronts have been stable, with only minor changes since the first historical accounts, and two glaciers, located at the southern edge of Cordillera Darwin, experienced advances in the last decade; namely Glaciar Garibaldi (1.1 km between 2001 and 2007), and a glacier calving into Bahía Pía $(0.6 \mathrm{~km}$ between 1991 and 2004) (Masiokas et al. 2009). These advancing glaciers seem to be responding to calving oscillations, and not necessarily to a climatic trend in the region characterized by atmospheric warming and a reduction in precipitation.

- A Chilean International Polar Year (IPY) project aimed to investigate the links between climate variability and glacier dynamics in the AP was collecting data between 2007 and 2009 at Fleming Glacier (69 $\left.30^{\circ} \mathrm{S}\right)$, the largest glacier flowing into Wordie Bay. Regional climate warming has caused Wordie ice shelf, among several other ice shelves in the AP to retreat and ultimately collapse during recent decades. Among the consequences of this atmospheric warming is the induced change in precipitation type, with more frequent liquid precipitation occurring in summer which is concurrent to higher air temperatures, and less frequent snow precipitation between 1970 and 2008 (Carrasco \& Quintana 2010). Glaciers flowing into these retreating ice shelves have primarily responded with ice-flow acceleration and thinning. Wordie Ice Shelf on the west coast of the AP, has experienced a major area reduction from $1926 \mathrm{~km}^{2}$ in 1966 (Wendt et al. 2010) to less than $55 \mathrm{~km}^{2}$ in year 2012 (Fig. 2).

Various data were collected during field campaigns to Fleming Glacier in austral summers 2007/08 and 2008/09. In situ measurements of ice-flow velocity first made in 1974 were repeated, confirming satellite-based assessments that velocity on the glacier has increased by $40-50 \%$ since 1974. Airborne laser data collected in December 2008 were compared to similar data collected in 2004 by the CECS/NASA team in collaboration with the Chilean Navy. This comparison yielded a thinning of the glacier, with increasing rates of thinning downstream, with a mean of $-4.1 \pm 0.25$ $\mathrm{m} \mathrm{a}^{-1}$ at the grounding line of the glacier (Wendt et al., 2010). These comparisons gave little indication that the glacier is achieving a new equilibrium. In contrast, Union Glacier, located at $80^{\circ} \mathrm{S}$ in the interior of Antarctica, reveals more stable conditions as it flows into the Constellation Inlet of the Ronne
Ice Shelf, which is not supposed to be vulnerable to the disintegration process currently affecting ice shelves in AP (Vaughan \& Spouge 2002). This has been revealed from the intense subglacial and surface mapping carried out since 2008 by means of a radar survey and GPS stake measurements (Rivera et al., 2010), showing the dynamical characteristics of this glacier, which are close to equilibrium.

\section{AKNOWLEDGEMENTS}

Centro de Estudios Científicos is sponsored by the Excellence Centres of CONICYT Basal Financing Programme and the Regional Government of Los Ríos. Several other public and private sources have provided technical and financial support to research and field work, including the Bicentennial Science and Technology Programme of CONICYT, INACH, FACh, Chilean Navy, FONDECYT project 1090387 and the Antarctic Logistics and Expeditions (ALE) company.

\section{LITERATURE CITED}

Aniya, M., H. Sato, R. Naruse, P. Skvarca \& G. Casassa 1997. Recent glacier variations in the Southern Patagonia Icefield, South America. Arctic and Alpine Research, 29(1):1-12.

Aravena, J.C. \& B. Luckman 2009. Spatio-temporal rainfall patterns in Southern South America. International Journal of Climatology, 29(14): 2106-2120.

Bown, F., A. Rivera, P. Zenteno, C. Bravo \& F. Cackwell. Accepted. First glacier inventory of Isla de Tierra del Fuego and adjacent islands in Southern Chile, and recent glacier variations. In: Kargel, J., G. Leonard \& A. Kááb, eds.), GLIMS book.

Carrasco, J., \& J. Quintana 2010. Climate variability and change in the Northern tip of the Antarctic Peninsula in response to atmospheric circulation. In: II International PAGES Symposium "Reconstructing Climate Variations in South America and the Antarctic Peninsula over the last 2000 years", 27-30 October, Valdivia, Chile, Abstract 227.

Fitz Roy, R. 1839. Narrative of the surveying voyages of His Majesty's Ships Adventure and Beagle between the years 1826 and 1836, 
describing their examination of the southern shores of South America, and the Beagle's circumnavigation of the globe. Proceedings of the second expedition, 1831-36, under the command of Captain Robert Fitz-Roy, R.N. London: Henry Colburn.

Homlund, P. \& H. Fuenzalida 1995. Anomalous glacier responses to 20th century climatic changes in Darwin Cordillera, southern Chile. Journal of Glaciology, 41(139):465-474.

Masiokas, M., A. Rivera, L. Espizúa, R. Villalba, S. Delgado \& J.C. Aravena 2009. Glacier fluctuations in extratropical South America during the past 1000 years. Palaeogeography, Palaeoclimatology, Palaeoecology, 281: 242-268.

Porter, C. \& A. Santana 2003. Rapid 20 ${ }^{\text {th }}$ century retreat of Ventisquero Marinelli in the Cordillera Darwin Icefield. Anales del Instituto de la Patagonia, 31:17-26.

Rasmussen, L.A., H. Conway \& C.F. Raymond 2007. Influence of upper air conditions on the Patagonia icefields. Global and Planetary Change, 59:203-216

Rignot, E., A. Rivera \& G. Casassa 2003. Contribution of the Patagonia icefields of South America to global sea level rise. Science, 302, 434-437.

Rignot, E. and 9 others. 2005. Recent ice loss from the Fleming and other glaciers, Wordie Bay, West Antarctic Peninsula. Geophysical Research Letters, 32(7), L07502. (10.1029/2004GL021947.)

Rivera, A. \& G. Casassa 2004. Ice elevation, areal, and frontal changes of glaciers from National
Park Torres del Paine, Southern Patagonia Icefield. Arctic, Antarctic and Alpine Research, 36(4):379-389.

Rivera, A., T. Benham, G. Casassa, J. Bamber \& J. Dowdeswell 2007. Ice elevation and areal changes of glaciers from the Northern Patagonia icefield, Chile. Global and Planetary Change, 59:126-137.

Rivera, A., R. Zamora, C. Rada, J. Walton \& S. Proctor 2010. Glaciological investigations on Union Glacier, Ellsworth Mountains, West Antarctica. Annals of Glaciology, 51(55): 91-96.

Rivera, A., F. Bown, D. Carrión \& P. Zenteno 2012a. Glacier responses to recent volcanic activity in Southern Chile. Environmental Research Letters, 7: doi:10.1088/17489326/7/014036

Rivera, A., J. Corripio, C. Bravo \& S. Cisternas 2012b. Glaciar Jorge Montt dynamics derived from photos obtained by fixed cameras and satellite image feature tracking. Annals of Glaciology, 53(60): 147-155.

Rivera, A., M. Koppes, C. Bravo, \& J. Aravena 2012c. Little Ice Age advance and retreat of Glaciar Jorge Montt, Chilean Patagonia. Climate of the Past, 8:403-414.

Vaughan, D.G. \& J.R. Spouge 2002. Risk Estimation of Collapse of the West Antarctic Ice Sheet. Climatic Change, 52 (1-2):65-91.

Wendt, J., A. Rivera, F. Bown, A. Wendt, R. Zamora, G. Casassa \& C. Bravo 2010. Recent ice elevation changes of Fleming glacier in response to the removal of Wordie ice shelf, Antarctic Peninsula. Annals of Glaciology, 51(55):97-102. 